お二人目は東京工業大学大学院総合理工学研究科物質電子化学専攻, 淵上・跡部研究室で学んだ Ho-Jung Luさんの滞在記 をご紹介します。

About author:

Ho-Jung Lu (呂 和榮, ローワエイ) was born in 1977 in Tainan, Taiwan. He received his B.Sc. degree in National Changhua University of Education (Changhua, Taiwan) and M. Sc. degree in National Tsing Hua University (Hsinchu, Taiwan) . He is currently working on his Ph. D. thesis under the supervisor of Prof. Biing-Jiun Uang. His research interests mainly involve asymmetric synthesis and protease inhibitors.

\title{
A Wonderful Memory in Tokyo Tech.
}

Ho-Jung Lu

Professor Toshio Fuchigami is mainly concerned with organic electrochemistry, organofluoride chemistry, and synthetic organic chemistry. Since 1990 he has published 113 research papers on these areas. It is to be highlighted that he has been successful in developing several methodologies for selective electrochemical fluorination. In the context of enormous potential of these studies, it is of great interest for me to learn these advanced techniques from his laboratory even though I do not have any experience in electrochemistry field. My research interests focused on asymmetric synthesis using camphor sulfonamide derivative as chiral auxiliary in Taiwan. Therefore I attempt to develop a new methodology for asymmetric synthesis by utilizing electrochemical techniques and apply them in my other future works.

Fortunately, I had a chance to study abroad owing to Asian Core Program, Taiwan this spring and Prof. Fuchigami provided me an opportunity to study in his esteemed laboratory. I stayed in his laboratory from March $16^{\text {th }}$ to May $15^{\text {th }}$. In my project, I tended to apply electrochemical methods for the preparation of chiral organofluorine compound $\mathbf{2}$ from camphor derivative $\mathbf{1}$ with high regioselectivity and diastereoselectivity (Scheme 1). In the preliminary results, the desired organofluorine compound $\mathbf{2}$ was obtained with high regioselectivity in moderate yield by constant current electrochemical oxidation of $\mathbf{1}$ in DME containing $\mathrm{Et}_{4} \mathrm{NF}$ $4 \mathrm{HF}(3 \mathrm{~F} / \mathrm{mol})$. However, right now, its diastereoseletivity has not been determined yet. I could not complete this project due to the limited time.

During my stay, I visited several places such as

\section{Scheme 1}

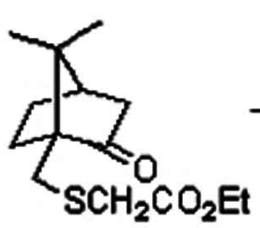

1

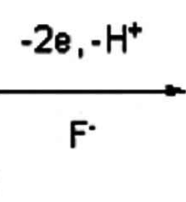

Scheme 1

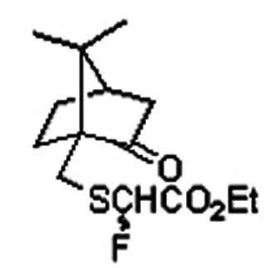

2

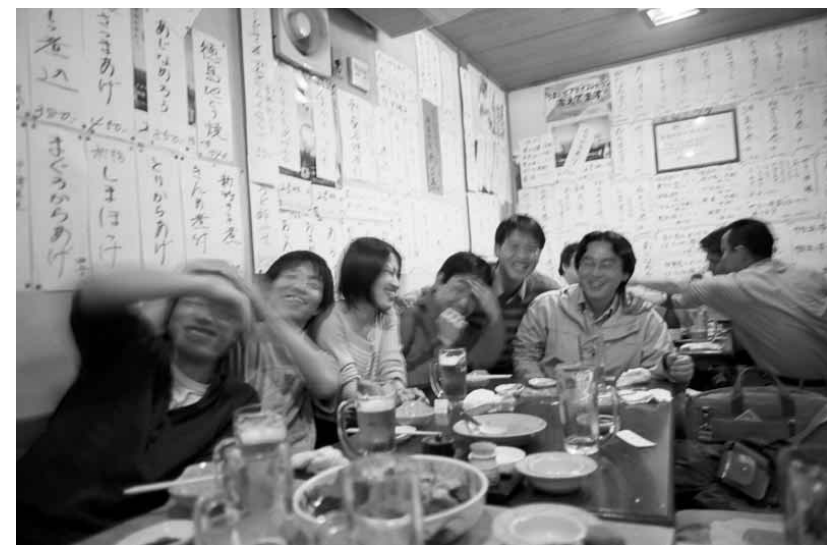

写真 2

Asakusa temple, Tsukiji (fish market), Akihabara(electronic town), Shijiku, Harajiku (shopping town), Tokyo tower, Hakone (hot spring resort) and tasted a lot of Japanese foods especially sashimi (raw fish). Except that, I found that Japanese are not only friendly to foreigners but also glad to help them. For this reason, I like Japan well.

Finally, I thank Prof. Fuchigami for taking care of me well and teaching me some electrochemistry, Assoc. Prof. Atobe for treating me well during my stay, and my supervisor Prof. Uang for giving me this opportunity to visit Tokyo Tech. I also thank my all dear friends in Prof. Fuchigami's laboratory, especially Nagura and Horri. Without all of them, I couldn't have this nice memory here. 